\title{
Danuta Makowicz-Poliszot*
}

\section{ANIMALS IN THE LIFE OF INHABITANTS OF THE NEOLITHIC SETTLEMENT AT NIEDŹWIEDŹ}

\begin{abstract}
Makowicz-Poliszot D. 2020. Animals in the life of inhabitants of the Neolithic settlement at Niedźwiedź. Sprawozdania Archeologiczne 72/1, 233-257.

This paper presents the results of zoological analyses of bone materials retrieved from Funnel Beaker culture features discovered in Niedźwiedź site 1 , Słomniki commune. The analyses included species and anatomic determinations, as well as determinations of the age, sex, and size of animals. The identified remains included bones of domestic (cattle, goats/sheep, pigs, and dogs) and wild mammals (horse, deer, roe deer, boar, beaver, hare, and small rodents), birds (mallard, common buzzard, and hawfinch), and a European pond turtle.
\end{abstract}

Keywords: Funnel Beaker culture, bone material, zoological analysis, mammals, birds, reptile

Received: 27.01.2020; Revised: 09.04.2020; Accepted: 19.05.2020

\section{METHODOLOGY OF RESEARCH}

Information concerning the animals that played a role in the life of people inhabiting the Neolithic settlement at Niedźwiedź (Słomniki commune) was obtained on the basis of zoological analyses of the bone material retrieved from Funnel Beaker culture (TRB) features discovered at site 1 in this locality. The analyses involved species and anatomic deter-

\footnotetext{
* Institute of Archaeology and Ethnology Polish Academy of Sciences, Sławkowska st. 17, 31-016 Kraków, Poland; danuta.mak@interia.pl
} 
minations, calculations of the total number of fragments (NISP - Number of Identified Specimens per Species) and the minimum number of individuals (MNI), bone measurements, and the determination of the age, sex, and size of animals.

When calculating the number of remains (NISP), it was accepted that fragments of one bone belonging to the same individual form a single osteological unit. The assessment of the minimum numbers of individuals was performed separately for particular features, and taking into account the diversity among animals in terms of age, sex, and size (Bökönyi 1970; Chaplin 1971, 70-75). The osteometric analysis of bones followed the study by A. Driesch (1976). The age at death was estimated based on the state of dentition and the state of epiphysial fusion. Four age classes were distinguished, corresponding with young (iuvenis), nearly adult (subadultus), adult and mature (adultus + maturus), and old individuals (senilis) (Uerpmann 1972, 15-16; Makowicz-Poliszot 1983, 269). Sex was determined for cattle, goat/sheep, and pig bones, with the diagnostic elements including horncores (cattle, goat, sheep), metacarpal bones (cattle), and mandibles with tusks or tusk alveoli (pig). Animal sizes were assessed based on measurements of selected bones and estimates of withers height, the latter calculated using appropriate indices: Matolcsi (1970) for cattle, Teichert (1975) for sheep, Teichert (1969) for pigs, and Harcourt (1974) for dogs. Metrical data obtained for cattle and pig bones (bone measurements in mm and withers heights in $\mathrm{cm}$ ) were given points on a scale from o to 100 in order to assess an animal's size. The scale was divided into three groups, corresponding with small animals (o-30 pts), mid-sized animals (31-70 pts), and large animals (71-10o pts) (Lasota-Moskalewska 2008, 242-243, 245).

\section{RESULTS}

The bone material from TRB features discovered at site 1 in Niedźwiedź comprised 4,179 bone remains, most of which (59.3\%) have been identified in terms of species and anatomy. They belong to mammals, birds, and one reptile. Mammal bones make up the largest group. They include bones of domestic mammals (cattle Bos taurus L., goat/sheep Capra hircus L./Ovis aries L., pig Sus domesticus L., and dog Canis familiaris L.), as well as wild mammals (horse Equus sp., deer Cervus elaphus L., roe deer Capreolus capreolus L., boar Sus scrofa L., beaver Castor fiber L., hare Lepus europaeus Pal.) and small rodents Rodentia (including hamster Cricetus cricetus L.; Tables 1-4).

The majority of mammal bones belong to domestic animals, 2,386 remains in total. Among them, the most well-represented group are cattle bones, whose percentages calculated in terms of NISP and MNI are the largest. Cattle are followed by goats/sheep and pigs in similar shares; goats/sheep are second in terms of NISP, while pigs move to second place when MNI is taken into account. The share of dog remains among domesticated mammals is small, not exceeding a few percent (Table 3). 
Among wild mammals, the largest proportions are those of Cervidae (regarded as one group: deer, roe deer), hare, and boar. Bird bones include remains of mallard Anas platyrhynchos L. (probably wild), common buzzard Buteo buteo L. (a large predatory bird from the Accipitridae family), and hawfinch Coccothraustes coccothraustes L. (a small passerine bird from the Fringillidae family). Reptiles are represented by shell fragments of a European pond turtle Emys orbicularis L. (Tables 4-5).

The age structure of cattle, goats/sheep, and pigs is presented in Table 6. Among these species, the highest proportions of remains (calculated based on NISP and MNI) belong to adult and mature animals, with the highest values recorded for cattle. The share of young and subadult individuals is comparable for cattle and pigs, while for goats/sheep the share of young individuals is strikingly high, at about $34 \%$. The proportions of old animals are relatively low for all these species, and do not rise above a few percent.

Domestic mammal remains represent nearly all parts of the skeleton, including phalanges. Bone remains of small ruminants include skeletons of 2 very young goats between 4 weeks and 3 months of age, while a portion of the dog bones belongs to an incomplete skeleton of a subadult individual between 7 months and 1.5-2 years of age (Table 7).

The remains of wild mammals (excluding bones of small rodents, which may be a modern admixture) belong to the trunk and hind leg (horse), the head (antler in particular) and single leg bones (deer, roe deer), the head and legs (pig), teeth (beaver), and the trunk and legs (hare) (Table 8).

The bones of cattle, goats/sheep, and pigs have been divided into those originating from body parts of high and low value for consumption (Tables 9-11). The anatomic distribution analysis for cattle and goats/sheep shows the prevalence of valuable parts of the carcass. The distribution is different for pig remains, where bones from parts of low value prevailed. Bones from the trunk (vertebrae, ribs) were most numerous among the parts valuable for consumption in the analysed species, while those of low value included primarily elements of the head, with their highest share recorded for pigs (nearly 46\%).

Sex was determined on the basis of bones of cattle, goats, sheep, and pigs. Cattle remains included elements belonging to 16 females, 3 males, and 4 castrates. One of the goat horncores was identified as male, and another one as female. The identified sheep bones belonged to 3 female animals and one castrate, while for pigs, one fragment belonged to a female animal and 4 to males (Tables 12, 16, 23, and 26).

Cattle size was determined based on withers height calculations and measurements of horncores, scapulae, humeri, radii, metacarpal bones, femora, tibiae, talus bones, calcanei, metatarsal bones, and first phalanges. Withers height values for cattle were calculated from the lengths of two metacarpal bones, one female and one male. The obtained values were $122.7 \mathrm{~cm}$ (female) and $136.1 \mathrm{~cm}$ (male), which means a mid-sized animal and a large animal. These data, combined with the measurements of bones, produced 151 points, which allowed for distinguishing mid-sized animals (which prevailed at 70.9\% of points), 


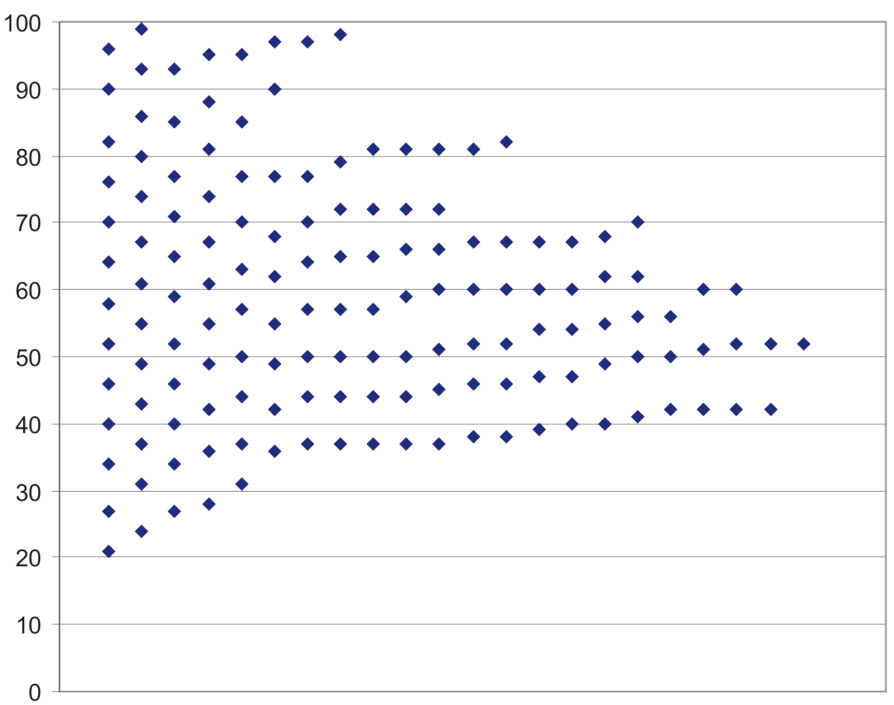

Fig. 1. Niedźwiedź, site. 1. Size distribution of cattle. Point scale. X-axis - points, $y$-axis - metrical data

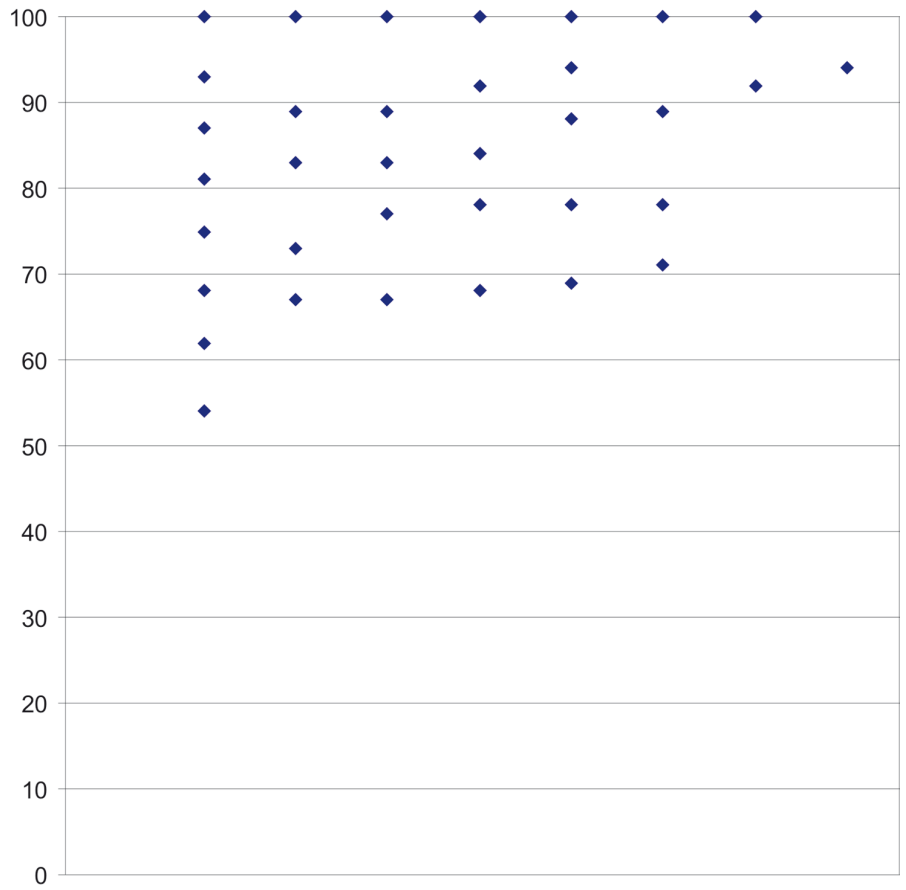

Fig. 2. Niedźwiedź, site. 1. Size distribution of pig. Point scale. X-axis - points, y-axis - metrical data 
large animals and animals from a transitional range between cattle and aurochs (25.8\% of points), and small animals (3.3\% of points) (Tables 12-22; Fig. 1).

For sheep, the size was determined based on the withers height, which was calculated from the lengths of two metacarpal bones and one metatarsal bone (Tables 24-25). The three values obtained were $62.1 \mathrm{~cm}, 62.3 \mathrm{~cm}$, and $59 \mathrm{~cm}$. The first two correspond to sheep of middle size, and the last one to a small individual (Lasota-Moskalewska et al. 1998, 324).

The withers height in pigs was calculated from the lengths of two metacarpal bones (III and IV), six talus bones, one calcaneus, and one metatarsal bone (IV), with the resulting values from $73.4 \mathrm{~cm}$ to $83.2 \mathrm{~cm}$. These data, combined with the measurements of scapulae, femora, tibiae, talus bones, and one calcaneus, produced 41 points, of which most (34 points) belong to large and transitional animals (from range between domesticated pig and boar) (Tables 27-33; Fig. 2).

For dog, the withers height was calculated as $40.5 \mathrm{~cm}$ by measuring a tibia. This value is characteristic of a small animal (Table 34; Wyrost 1963, 227; Bökönyi 1984, 66).

\section{CONCLUSIONS}

The majority of bone remains from Niedźwiedź represent the typical post-consumption material. This is indicated by significant bone fragmentation (40.7\% undetermined fragments) and the occurrence of meat eating traces, for instance numerous traces of fire (on remnants of domestic and wild mammals), cut marks (on cattle ribs), or chop marks (mainly on cattle longbone shafts). Traces of fire are leftovers from roasting meat with bones, cut marks formed when the meat was filleted during the meal, and chop marks are evidence for marrow extraction (Lasota-Moskalewska 2008, 190, 194-195).

Quantitative analysis of the bone material from the discussed site reveals a clear prevalence of domestic mammal remains over wild mammal remains, amounting to $97.3 \%$ in terms of NISP and $89.6 \%$ in terms of MNI. Thus, domestic mammals were the basic source of meat for the inhabitants of the Neolithic settlement at Niedźwiedź. Breeding these animals played a major role in the economy, with hunting for wild mammals playing a much less prominent role. The largest group among the remains of domestic mammals was that of cattle bones, and beef played a fundamental role in consumption. Cattle was the most well-represented species in the livestock, while the shares of small ruminants and pig in the livestock and in consumption were smaller. Their proportions, calculated in terms of NISP and MNI, are considerably lower than for cattle. Dog was the least represented species in the bone material, and played a very limited role in the life of the Neolithic inhabitants of the Niedźwiedź settlement. Some long bones of this species (humerus, femur, tibia) bear traces of burning, which suggests that dog meat was also consumed (Tables 2-3).

The results of quantitative analysis of the animal bones from Niedźwiedź have been compared to analogical results obtained by the author of the article for other TRB sites 


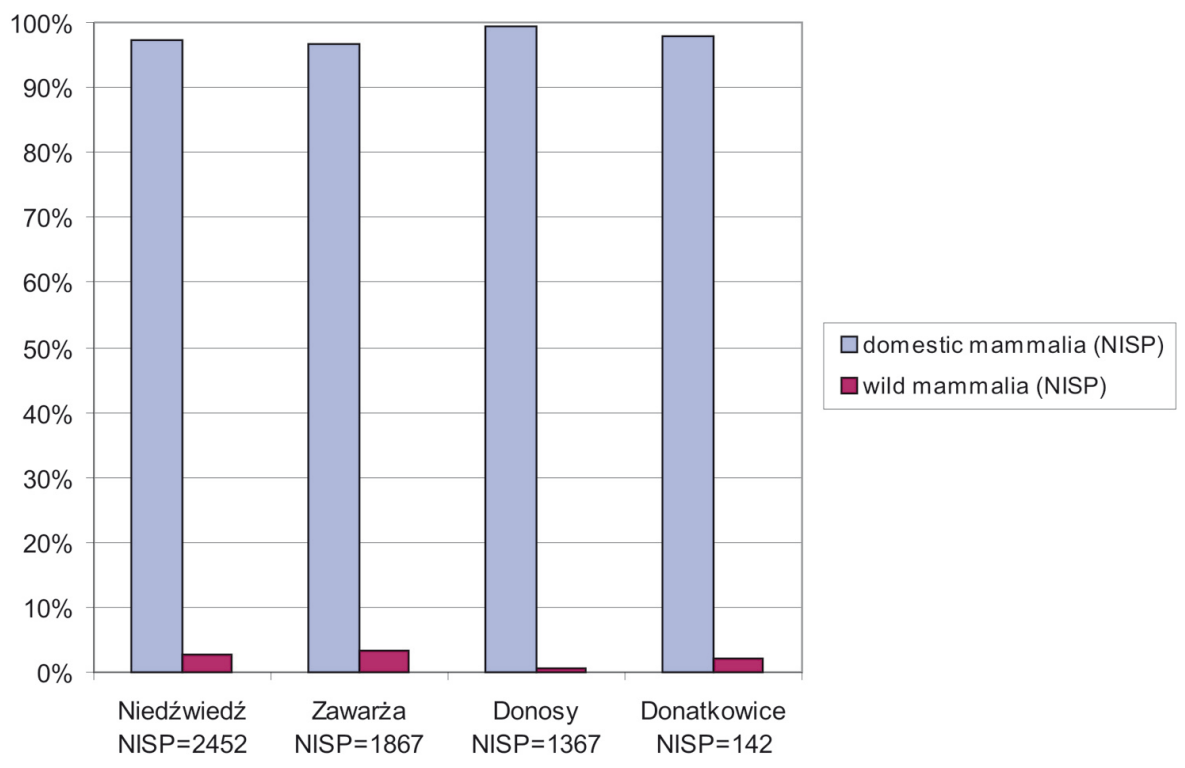

Fig. 3. Percentage of domestic and wild mammalia according to the number of bones (NISP) in the bone material from the TRB sites in the loess uplands of western Lesser Poland

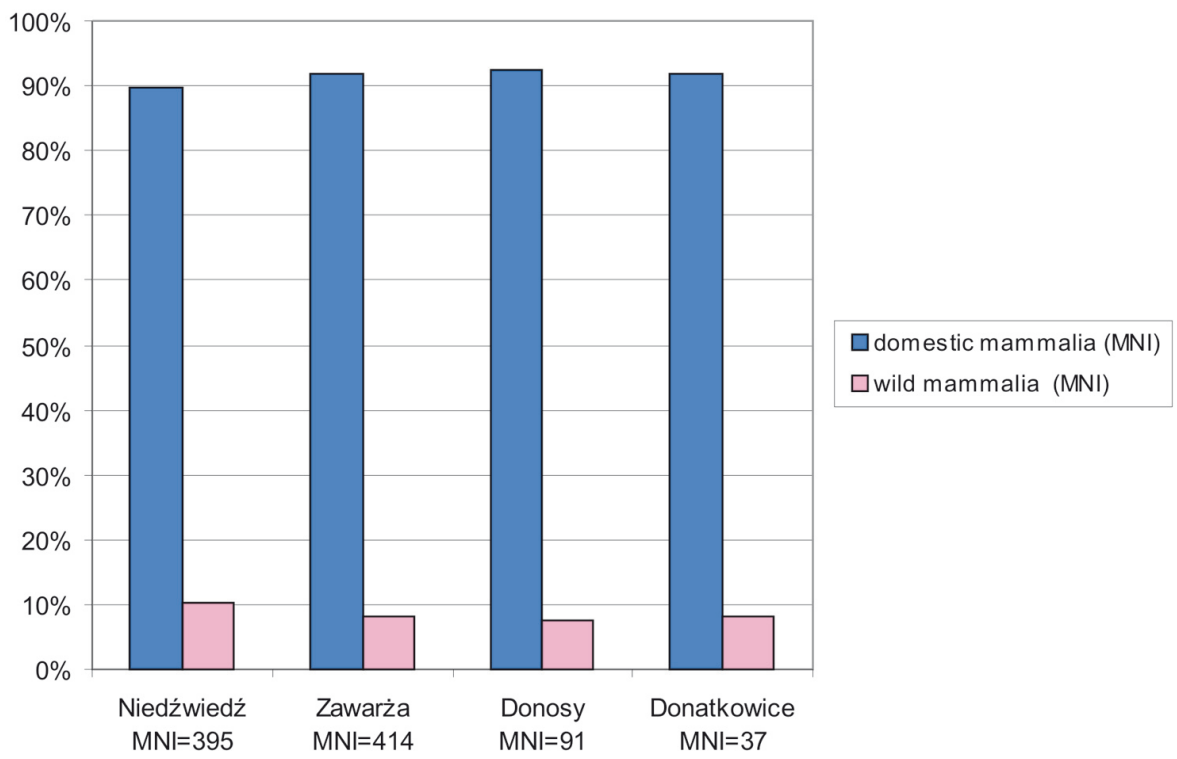

Fig. 4. Percentage of domestic and wild mammalia according to the minimum number of individuals (MNI) in the bone material from the TRB sites in the loess uplands of western Lesser Poland 


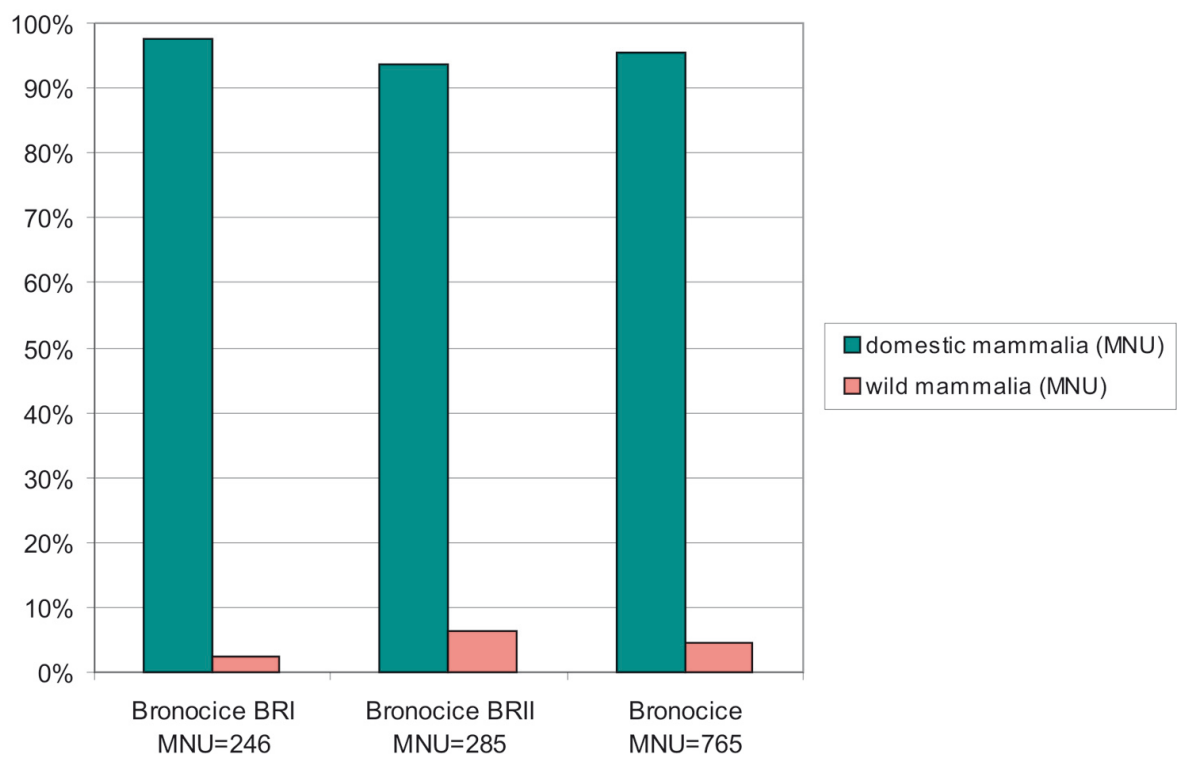

Fig. 5. Percentage of domestic and wild mammalia according to the minimum number of bone units (MNU) in the bone material from the TRB site in Bronocice

situated in the loess uplands of western Lesser Poland (upper Vistula basin), such as Zawarża, Donosy, Donatkowice and Bronocice (phases 1, 3, 4; BR I-III). For comparative purposes, such analyses from a few other TRB sites in southeastern Poland were also taken into account, including Ćmielów, Kamień Łukawski, Zawichost-Podgórze, and Gródek Nadbużny. Bone assemblages from all these sites also show a notable predominance of domestic mammals over wild mammals (as in Niedźwiedź), from 92.5\% to 99.3\% NISP, from $91.8 \%$ to $92.3 \%$ MNI, and from 93.7\% to 97.6\% MNU (Minimum Number of bone Units; Bronocice). The analysis of anatomical distribution of domestic mammal remains in the comparative materials reveals the largest proportions of cattle, followed by either goat/sheep or pig in second place, or with similar shares of these two latter species. In most of these assemblages dog comes last in terms of the number of bones (Figs 3-10; Kruk 1980, 301-303; Krysiak 1950; 1952; 1956; 1966; Krysiak and Lasota 1971; Makowicz-Poliszot 2002, 136, 138-140, 142; 2007, 145, 148, 150, 151, 153, 176, 177, 179; Milisauskas et al. 2012, 24-27).

For the Neolithic settlement at Niedźwiedź, age structure has been analysed for cattle, small ruminants, and pig. As for cattle, the predominance of adult and mature individuals in the bone material indicates that animals were kept not only for meat, but also for their milk, labour, and manure. A much greater proportion (than in cattle) of young goats/sheep suggests breeding these animals mainly for meat, or selective culling in connection with 


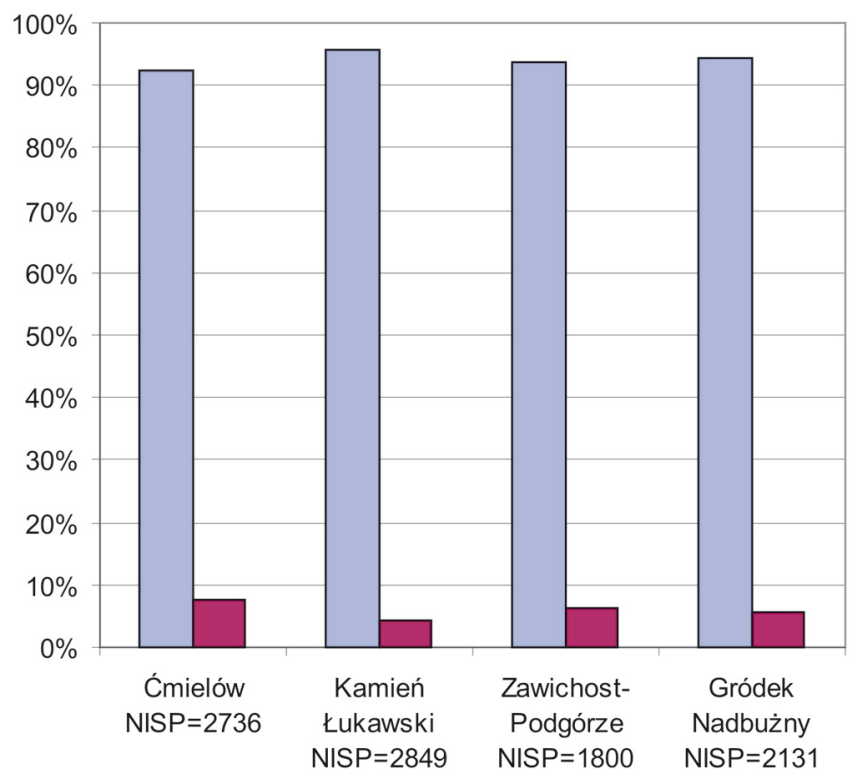

$\square$ domestic mammalia (NISP)

$\square$ wild mammalia (NISP)

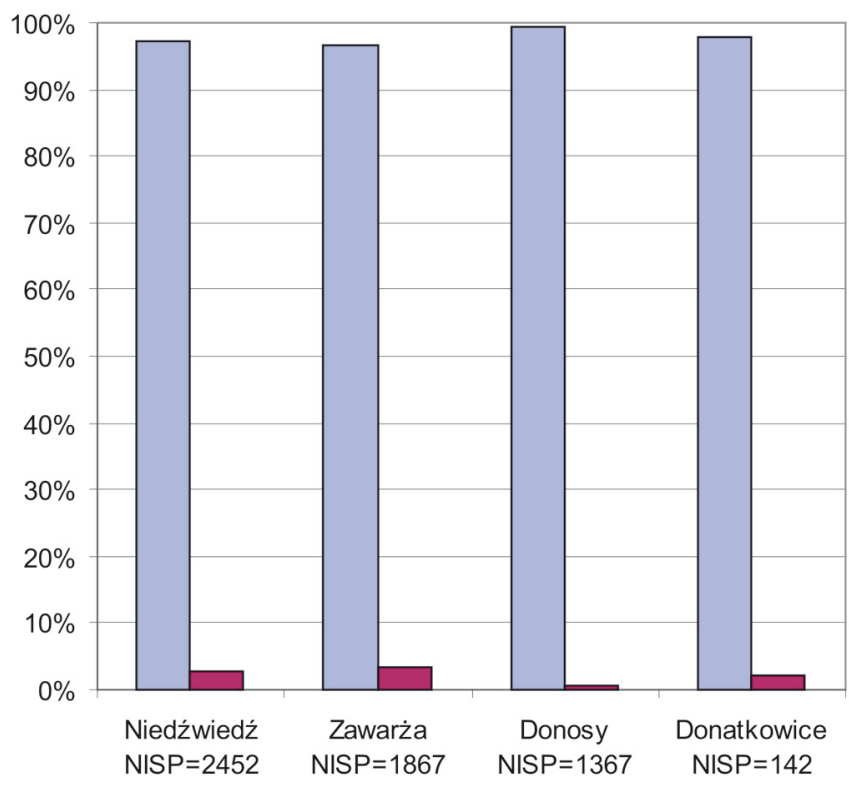

$\square$ domestic mammalia (NISP)

$\square$ wild mammalia (NISP)

Fig. 6. Percentage of domestic and wild mammalia according to the number of bones (NISP) in the bone material from the TRB sites in southeastern Poland 


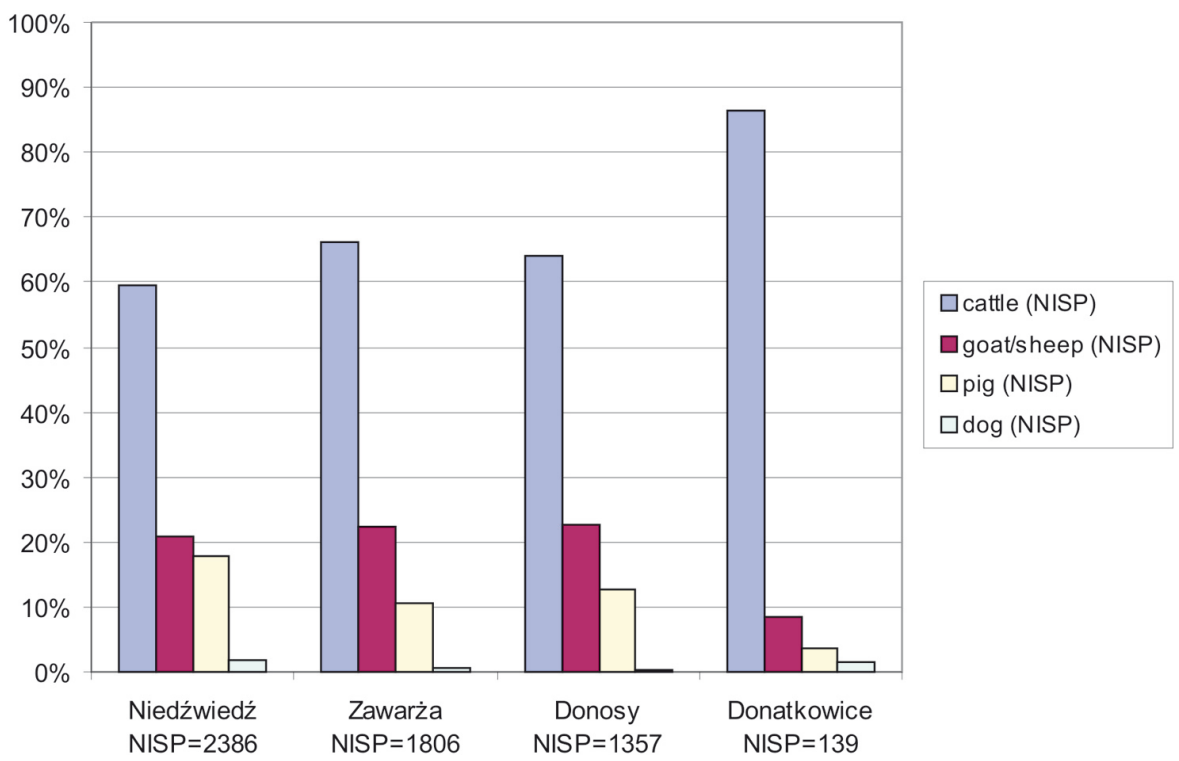

Fig. 7. Percentage of domestic mammalia according to the number of bones (NISP) in the bone material from the TRB sites in the loess uplands of western Lesser Poland

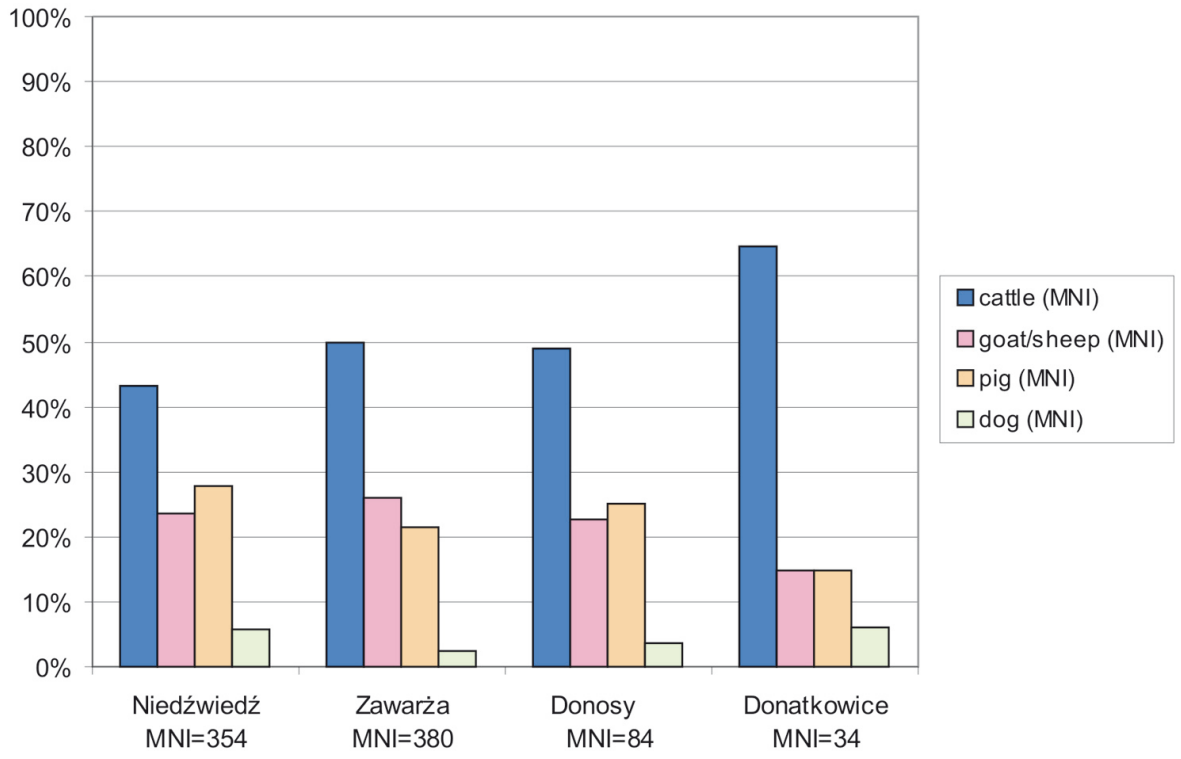

Fig. 8. Percentage of domestic mammalia according to the minimum number of individuals (MNI) in the bone material from the TRB sites in the loess uplands of western Lesser Poland 


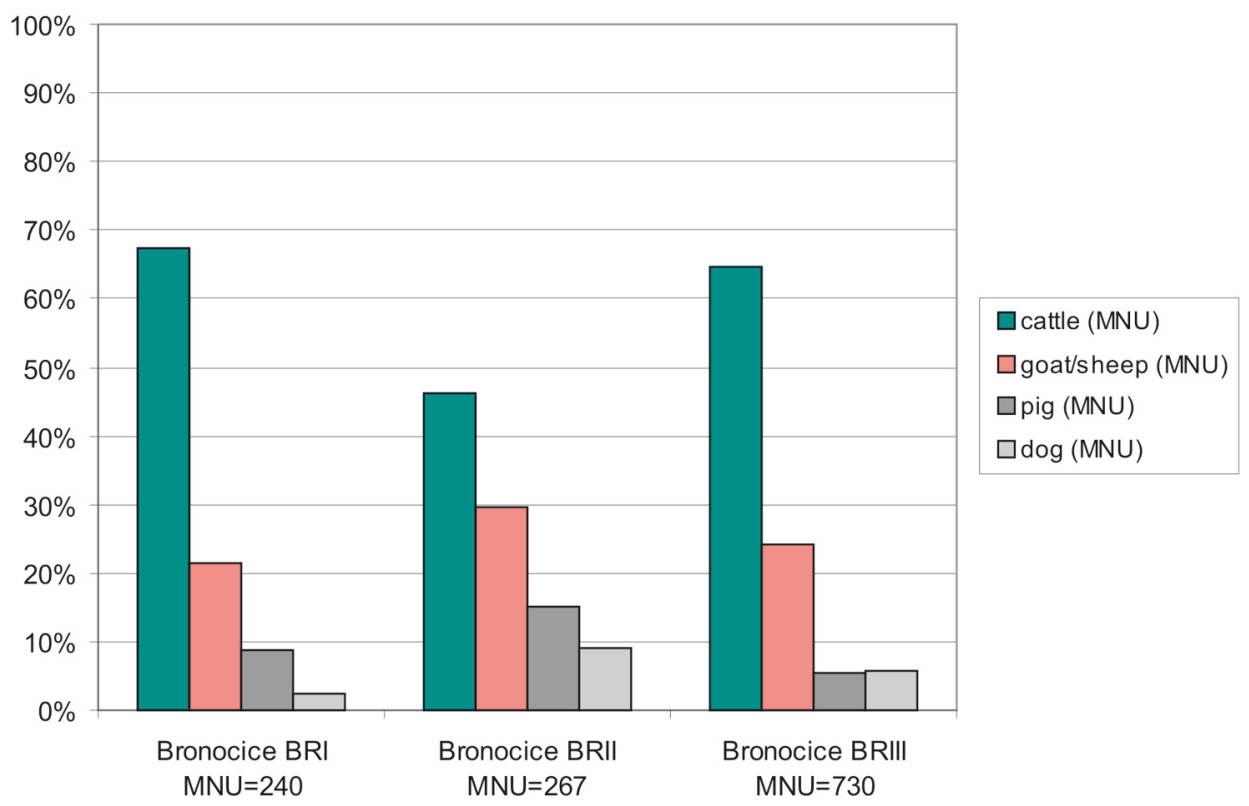

Fig. 9. Percentage of domestic mammalia according to the minimum number of bone units (MNU) in the bone material from the TRB site in Bronocice

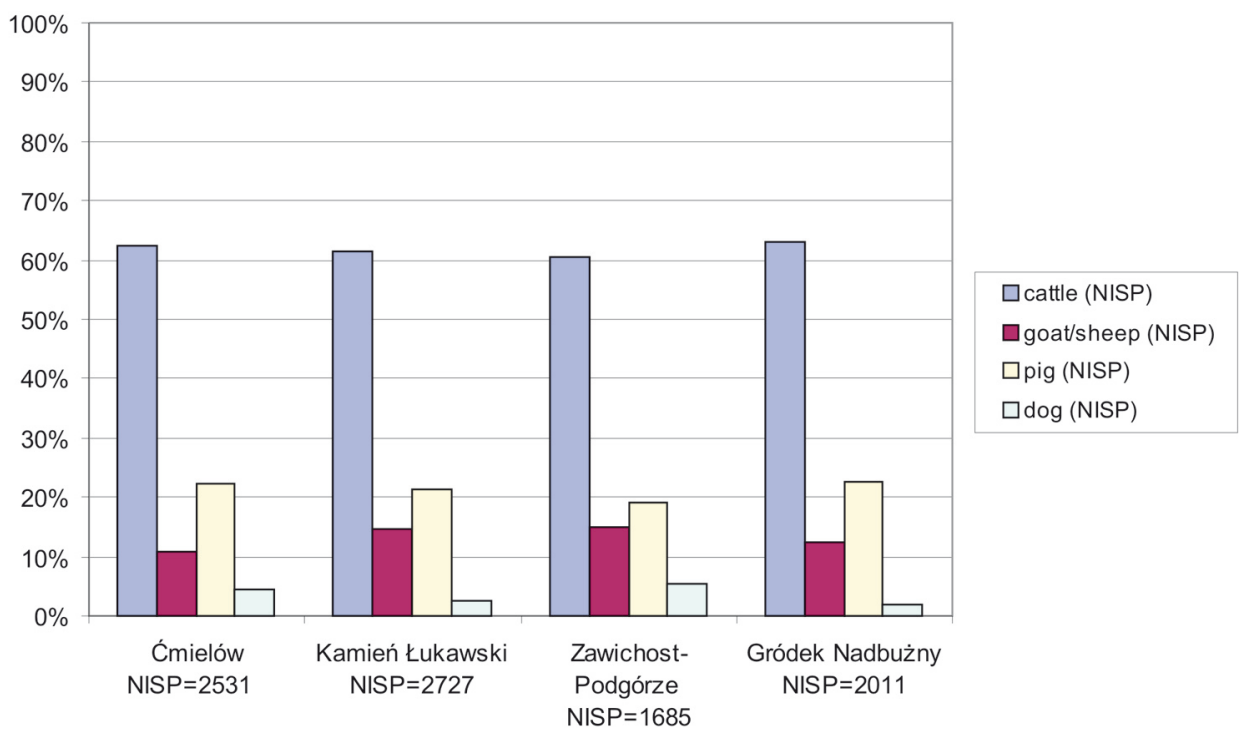

Fig. 10. Percentage of domestic mammalia according to the number of bones (NISP) in the bone material from the TRB sites in southeastern Poland 
fodder shortages. Analysis of the age at death of pigs, with the number of mature individuals slightly higher than that of young and subadult animals (calculated jointly) may be indicative of breeding oriented towards the production of meat and fat (Table 6).

The distribution of bones of major meat-producing species: cattle, goat/sheep, and pig in terms of consumption value (with low-value parts including slaughter waste) reveals a preference for carcass parts belonging to the trunk. These correspond to such (currently identified) parts of the carcass as the neck (in all the mentioned species), prime rib and brisket in cattle and goats/sheep, flat rib, fore rib, and rump cut in cattle, saddle in goats/ sheep, and loin, ribs, and bacon in pigs. The diet was also supplemented with edible parts of the head (primarily pigs), such as the brain and tongue (Tables 9-11; Głowacka 1964; Milisauskas et al. 2012, 157).

Conclusions concerning breeding structure can be derived from sex determinations for cattle and sheep. For cattle, the majority of the determinations points to female individuals. This allows one to assume that cows, bred for milk, were prevalent in the herd. Apart from cow remains, the bone material included skeletal elements belonging to bulls and oxen, the latter possibly used for traction. The inhabitants of the Neolithic settlement at Niedźwiedź castrated not only bulls, but also rams, as evidenced by the identification among sheep bones of a horncore belonging to a castrated individual. Castrated rams could have been harnessed as well, which is suggested by (among other data) a Neolithic figurine of two rams (previously interpreted as "oxen") in a yoke, discovered in Krężnica Jara in Lubelskie Province, Poland (Tables 12, 16, 23; Lasota-Moskalewska 2005, 108).

Animal size was determined for cattle, sheep, pig, and dog. The osteometric analysis of the cattle bones identified primarily mid-sized and large individuals. Three fragments originate from animals representing transitional forms between cattle and aurochs, or crossbreeds of these two species. Withers height calculations for sheep suggest breeding of small (up to $59.9 \mathrm{~cm}$ ) and mid-sized animals (60.0-69.9 cm; Lasota-Moskalewska et al. 1998, 324), while pig size determinations indicate that mainly large animals were bred. Several pig bones belong to crossbreeds of domesticated pig and boar. The height calculated for the only dog from Niedźwiedź corresponds with that of a small individual (Tables 12-22, 24-25, 27-34; Figs 1-2).

The small proportion of wild mammals in the bone material from Niedźwiedź, amounting to $2.7 \%$ in terms of NISP and $10.4 \%$ in terms of MNI, is indicative of a very limited role of hunting in meat acquisition. Low shares of wild mammals have also been recorded in bone assemblages from comparative sites, and they fall within ranges of $0.7 \%$ to $7.5 \%$ NISP, $7.7 \%$ to $8.2 \%$ MNI, and $2.4 \%$ to $6.3 \%$ MNU. Cervidae (deer and roe deer) were the most often hunted species in Niedźwiedź, followed by hare and boar. Wild horses and beavers were also hunted, as well as birds such as mallard, common buzzard, and hawfinch. The bone assemblage from Niedźwiedź also included remains of the European pond turtle, which may have played some role in the diet (Tables 2, 4-5; Figs 3-5; MakowiczPoliszot 2002, 138-142; 2007, 147, 149, 150, 152-154; 177-180; Milisauskas et al. 2012, 24, 25). 
Table 1. Niedźwiedź, site 1. List of animal remains

\begin{tabular}{|l|c|c|}
\hline \multirow{2}{*}{ Group of animals } & \multicolumn{2}{|c|}{ NISP } \\
\cline { 2 - 3 } & $\mathrm{n}$ & $\%$ \\
\hline Domestic mammalia & 2386 & 57,1 \\
\hline Wild mammalia & 66 & 1,6 \\
\hline Birds & 22 & 0,5 \\
\hline Reptiles & 3 & 0,1 \\
\hline Undetermined & 1702 & 40,7 \\
\hline Total & 4179 & 100 \\
\hline
\end{tabular}

Table 2. Niedźwiedź, site 1. Participation of domestic and wild mammalia in the bone material

\begin{tabular}{|l|c|c|c|c|}
\hline \multirow{2}{*}{ Group of animals } & \multicolumn{2}{|c|}{ NISP } & \multicolumn{2}{c|}{ MNI } \\
\cline { 2 - 5 } & $\mathrm{n}$ & $\%$ & $\mathrm{n}$ & $\%$ \\
\hline Domestic mammalia & 2386 & 97,3 & 354 & 89,6 \\
\hline Wild mammalia & 66 & 2,7 & 41 & 10,4 \\
\hline Total & 2452 & 100 & 395 & 100 \\
\hline
\end{tabular}

Table 3. Niedźwiedź, site 1. Participation of particular species of domestic mammalia in the bone material

\begin{tabular}{|l|c|c|c|c|}
\hline \multirow{2}{*}{\multicolumn{1}{|c|}{ Species }} & \multicolumn{2}{c|}{ NISP } & \multicolumn{2}{c|}{ MNI } \\
\cline { 2 - 5 } & $\mathrm{n}$ & $\%$ & $\mathrm{n}$ & $\%$ \\
\hline Bos taurus L. & 1421 & 59,6 & 153 & 43,2 \\
\hline Capra hircus L./Ovis aries L. & 495 & 20,7 & 83 & 23,5 \\
\hline Sus domesticus L. & 428 & 17,9 & 98 & 27,7 \\
\hline Canis familiaris L. & 42 & 1,8 & 20 & 5,6 \\
\hline Total & 2386 & 100 & 354 & 100 \\
\hline
\end{tabular}


Table 4. Niedźwiedź, site 1. Participation of particular species of wild mammalia in the bone material

\begin{tabular}{|l|c|c|c|c|}
\hline \multirow{2}{*}{ Species } & \multicolumn{2}{|c|}{ NISP } & \multicolumn{2}{c|}{ MNI } \\
\cline { 2 - 5 } & $\mathrm{n}$ & $\%$ & $\mathrm{n}$ & $\%$ \\
\hline Equus sp. & 4 & 6,1 & 3 & 7,3 \\
\hline Cervus elaphus L. & 13 & 19,7 & 11 & 26,9 \\
\hline Capreolus capreolus L. & 4 & 6,1 & 3 & 7,3 \\
\hline Sus scrofa L. & 11 & 16,7 & 6 & 14,6 \\
\hline Castor fiber L. & 2 & 3,0 & 1 & 2,4 \\
\hline Lepus europaeus Pal. & 18 & 27,3 & 9 & 22,0 \\
\hline Cricetus cricetus L. & 10 & 15,0 & 5 & 12,2 \\
\hline Rodentia & 4 & 6,1 & 3 & 7,3 \\
\hline Total & 66 & 100 & 41 & 100 \\
\hline
\end{tabular}

Table 5. Niedźwiedź, site 1. Participation of particular species of birds and reptile in the bone material

\begin{tabular}{|l|l|c|c|c|c|}
\hline \multirow{2}{*}{$\begin{array}{c}\text { Group } \\
\text { of animals }\end{array}$} & \multicolumn{2}{|c|}{ Species } & \multicolumn{2}{c|}{ NISP } & \multicolumn{2}{c|}{ MNI } \\
\cline { 3 - 6 } & & $\mathrm{n}$ & $\%$ & $\mathrm{n}$ & $\%$ \\
\hline \multirow{4}{*}{ Birds } & Anas platyrhynchos L. & 2 & 9,1 & 1 & 25,0 \\
\cline { 2 - 6 } & Buteo buteo L. & 1 & 4,6 & 1 & 25,0 \\
\cline { 2 - 6 } & Coccothraustes coccothraustes L. & 16 & 72,7 & 1 & 25,0 \\
\cline { 2 - 6 } & Undetermined & 3 & 13,6 & 1 & 25,0 \\
\cline { 2 - 6 } & Total & 22 & 100 & 4 & 100 \\
\hline Reptile & Emys orbicularis (L.) & 3 & 100 & 3 & 100 \\
\hline
\end{tabular}

Table 6. Niedźwiedź, site 1. Age structure of cattle, goats/sheep and pig in the bone material

\begin{tabular}{|l|c|c|c|c|c|c|c|c|c|c|c|c|}
\hline \multirow{2}{*}{$\begin{array}{c}\text { Class of } \\
\text { age }\end{array}$} & \multicolumn{4}{|c|}{ Cattle } & \multicolumn{4}{c|}{ Goats/sheep } & \multicolumn{4}{c|}{ Pigs } \\
\cline { 2 - 16 } & \multicolumn{2}{|c|}{ NISP } & \multicolumn{2}{|c|}{ MNI } & \multicolumn{2}{c|}{ NISP } & \multicolumn{2}{c|}{ MNI } & \multicolumn{2}{c|}{ NISP } & \multicolumn{2}{c|}{ MNI } \\
\cline { 2 - 14 } & $\mathrm{n}$ & $\%$ & $\mathrm{n}$ & $\%$ & $\mathrm{n}$ & $\%$ & $\mathrm{n}$ & $\%$ & $\mathrm{n}$ & $\%$ & $\mathrm{n}$ & $\%$ \\
\hline iuvenis & 148 & 18,4 & 28 & 19,0 & 97 & 33,8 & 26 & 34,2 & 64 & 21,3 & 20 & 21,7 \\
\hline subadultus & 113 & 14,0 & 31 & 21,1 & 34 & 11,8 & 15 & 19,7 & 51 & 17,0 & 22 & 23,9 \\
\hline $\begin{array}{l}\text { adultus } \\
+ \text { maturus }\end{array}$ & 544 & 67,5 & 87 & 59,2 & 155 & 54,0 & 34 & 44,8 & 177 & 59,0 & 44 & 47,9 \\
\hline senilis & 1 & 0,1 & 1 & 0,7 & 1 & 0,4 & 1 & 1,3 & 8 & 2,7 & 6 & 6,5 \\
\hline Total & 806 & 100 & 147 & 100 & 287 & 100 & 76 & 100 & 300 & 100 & 92 & 100 \\
\hline
\end{tabular}


Table 7. Niedźwiedź, site 1. Elements of the skeleton of domestic mammalia in the bone material

\begin{tabular}{|c|c|c|c|c|c|c|c|c|}
\hline \multirow{2}{*}{\begin{tabular}{|l|}
\multicolumn{1}{|c|}{$\begin{array}{c}\text { Element of } \\
\text { skeleton }\end{array}$} \\
$\begin{array}{l}\text { Processus } \\
\text { cornualis }\end{array}$ \\
\end{tabular}} & \multirow{2}{*}{\begin{tabular}{|c}
$\begin{array}{c}\text { Bos } \\
\text { taurus L. }\end{array}$ \\
34 \\
\end{tabular}} & \multirow{2}{*}{$\begin{array}{c}\text { Capra hircus } \mathbf{L} . \\
\text { Ovis aries L. } \\
-\end{array}$} & \multirow{2}{*}{$\begin{array}{c}\begin{array}{c}\text { Ovis } \\
\text { aries L. }\end{array} \\
9\end{array}$} & \multicolumn{2}{|c|}{$\begin{array}{c}\text { Capra } \\
\text { hircus L. }\end{array}$} & \multirow{2}{*}{$\begin{array}{c}\text { Sus dome- } \\
\text { sticus L. } \\
-\end{array}$} & \multicolumn{2}{|c|}{$\begin{array}{c}\text { Canis } \\
\text { familiaris } \mathbf{L} .\end{array}$} \\
\hline & & & & 5 & 1 & & - & - \\
\hline Cranium & 105 & 32 & 2 & - & 1 & 56 & 6 & 1 \\
\hline Mandibula & 109 & 41 & - & - & 4 & 76 & 4 & 1 \\
\hline Dentes & 103 & 52 & - & - & - & 63 & 2 & - \\
\hline Os hyoideum & 1 & 3 & - & - & - & - & - & - \\
\hline $\begin{array}{l}\text { Vertebrae } \\
\text { cervicales }\end{array}$ & 60 & 13 & - & - & 5 & 4 & 5 & 13 \\
\hline $\begin{array}{l}\text { Vertebrae } \\
\text { thoracales }\end{array}$ & 43 & 10 & - & - & - & 10 & 2 & 18 \\
\hline $\begin{array}{l}\text { Vertebrae } \\
\text { lumbales }\end{array}$ & 59 & 13 & - & - & 10 & 6 & - & 7 \\
\hline Sacrum & 4 & - & - & - & 1 & - & 1 & 1 \\
\hline $\begin{array}{l}\text { Vertebrae } \\
\text { caudales }\end{array}$ & 7 & - & - & - & - & - & - & - \\
\hline Vertebrae & 11 & 3 & - & - & 23 & 2 & - & - \\
\hline Costae & 230 & 89 & - & - & 40 & 52 & 5 & 39 \\
\hline Sternum & - & - & - & - & 1 & - & - & 1 \\
\hline Scapula & 76 & 12 & 1 & - & 3 & 10 & 2 & 2 \\
\hline Humerus & 44 & 15 & 2 & - & 3 & 27 & 2 & 1 \\
\hline Radius & 46 & 35 & 3 & - & 3 & 7 & - & 2 \\
\hline Ulna & 26 & 5 & 1 & - & 3 & 14 & 1 & 2 \\
\hline Carpalia & 26 & - & - & - & 12 & 1 & - & 3 \\
\hline Metacarpus & 42 & 23 & 9 & - & 3 & 8 & 1 & 1 \\
\hline Pelvis & 58 & 7 & 4 & - & 2 & 2 & 1 & - \\
\hline Femur & 66 & 20 & - & - & 4 & 9 & 3 & - \\
\hline Patella & 4 & - & - & - & 1 & 3 & - & - \\
\hline Tibia & 73 & 25 & - & - & 4 & 27 & 3 & - \\
\hline $\begin{array}{l}\text { Fibula, } \\
\text { os malleolare }\end{array}$ & 1 & 1 & - & - & 2 & 4 & - & - \\
\hline Tarsalia & 61 & 4 & 3 & - & 15 & 16 & - & - \\
\hline Metatarsus & 56 & 24 & 5 & - & 4 & 6 & 4 & - \\
\hline Metapodium & 10 & 5 & - & - & - & 10 & 4 & 1 \\
\hline Phalanx I & 45 & 16 & - & - & 11 & 8 & 1 & 3 \\
\hline Phalanx II & 35 & 2 & - & - & 5 & 5 & - & - \\
\hline Phalanx III & 10 & 2 & - & - & 4 & 2 & - & - \\
\hline $\begin{array}{l}\text { Ossa } \\
\text { sesamoidea }\end{array}$ & 8 & - & - & - & 1 & - & - & - \\
\hline Total & 1453 & 452 & 39 & 5 & $166^{*}$ & 428 & 47 & $96^{* *}$ \\
\hline
\end{tabular}

* - skeletons of two very young individuals, ${ }^{*}$ - part of the skeleton of almost adult individual 
Table 8. Niedźwiedź, site 1. Elements of the skeleton of wild mammalia in the bone material

\begin{tabular}{|l|c|c|c|c|c|c|}
\hline $\begin{array}{c}\text { Element } \\
\text { of skeleton }\end{array}$ & Equus sp. & $\begin{array}{c}\text { Cervus } \\
\text { elaphus L. }\end{array}$ & $\begin{array}{c}\text { Capreolus } \\
\text { capreolus L. }\end{array}$ & $\begin{array}{c}\text { Sus } \\
\text { scrofa L. }\end{array}$ & $\begin{array}{c}\text { Castor fiber } \\
\text { L. }\end{array}$ & $\begin{array}{c}\text { Lepus eu- } \\
\text { ropaeus Pal. }\end{array}$ \\
\hline Os cornu & - & 8 & 3 & - & - & - \\
\hline Cranium & - & - & - & 1 & - & - \\
\hline Mandibula & - & - & - & 1 & - & - \\
\hline Dentes & - & 1 & - & 2 & 2 & - \\
\hline $\begin{array}{l}\text { Vertebrae } \\
\text { lumbales }\end{array}$ & 1 & - & - & - & - & 1 \\
\hline Costae & 1 & - & - & - & - & 1 \\
\hline Scapula & - & - & - & - & - & 3 \\
\hline Humerus & - & - & - & 3 & - & 1 \\
\hline Radius & - & 1 & - & - & - & 1 \\
\hline Ulna & - & - & - & 2 & - & 3 \\
\hline Carpalia & - & - & - & 1 & - & \\
\hline Metacarpus & - & - & - & - & - & 1 \\
\hline Femur & 1 & - & - & - & - & \\
\hline Tibia & 1 & - & - & - & - & \\
\hline Metatarsus & - & 1 & 1 & 1 & - & 8 \\
\hline Metapodium & - & 1 & - & - & - & - \\
\hline Phalanx I & - & 1 & - & - & - & - \\
\hline Total & 4 & 13 & 4 & 11 & 2 & 19 \\
\hline
\end{tabular}

Table 9. Niedźwiedź, site 1. More and less valuable body parts of cattle based on the bone material

\begin{tabular}{|l|l|c|c|}
\hline \multicolumn{2}{|c|}{ Anatomical part } & n & $\%$ \\
\hline \multirow{4}{*}{$\begin{array}{l}\text { Valuable parts } \\
\text { of carcass }\end{array}$} & Trunk (neck, prime rib, brisket, flat rib, fore rib, rump cut) & 407 & 28,0 \\
\cline { 2 - 4 } & Proximal parts of fore limb (shoulder, fore shank) & 192 & 13,2 \\
\cline { 2 - 4 } & Proximal parts of rear limb (leg, hind shank) & 202 & 13,9 \\
\cline { 2 - 4 } & Total & 801 & 55,1 \\
\hline \multirow{4}{*}{$\begin{array}{l}\text { Not very valuable } \\
\text { parts of carcass }\end{array}$} & Head (brawn) & 352 & 24,2 \\
\cline { 2 - 4 } & Distal parts of fore limb (trotters/feet) & 122 & 8,4 \\
\cline { 2 - 4 } & Distal parts of rear limb (trotters/feet) & 171 & 11,8 \\
\cline { 2 - 4 } & Others (teil) & 7 & 0,5 \\
\cline { 2 - 4 } & Total & 652 & 44,9 \\
\hline \multirow{2}{*}{ Total } & & 1453 & 100 \\
\hline
\end{tabular}


Table 10. Niedźwiedź, site 1. More and less valuable body parts of goats/sheep based on the bone material

\begin{tabular}{|l|l|c|c|}
\hline \multicolumn{2}{|c|}{ Anatomical part } & n & \% \\
\hline \multirow{4}{*}{$\begin{array}{l}\text { Valuable parts } \\
\text { of carcass }\end{array}$} & Trunk (neck, prime rib, brisket, saddle) & 128 & 25,8 \\
\cline { 2 - 4 } & Proximal parts of fore limb (shoulder, fore shank) & 74 & 14,9 \\
\cline { 2 - 4 } & Proximal parts of rear limb (leg, hind shank) & 57 & 11,5 \\
\cline { 2 - 4 } & Total & 259 & 52,2 \\
\hline \multirow{3}{*}{$\begin{array}{l}\text { Not very valuable } \\
\text { parts of carcass }\end{array}$} & Head (brawn) & 144 & 29,0 \\
\cline { 2 - 4 } & Distal parts of fore limb (trotters/feet) & 45 & 9,1 \\
\cline { 2 - 4 } & Distal parts of rear limb (trotters/feet) & 48 & 9,7 \\
\cline { 2 - 4 } & Total & 237 & 47,8 \\
\hline Total & & 496 & 100 \\
\hline
\end{tabular}

Table 11. Niedźwiedź, site 1. More and less valuable body parts of pigs based on the bone material

\begin{tabular}{|l|l|c|c|}
\hline \multicolumn{2}{|c|}{ Anatomical part } & n & $\%$ \\
\hline \multirow{4}{*}{$\begin{array}{l}\text { Valuable parts of } \\
\text { carcass }\end{array}$} & Trunk (neck, loin, ribs, bacon) & 74 & 17,3 \\
\cline { 2 - 4 } & Proximal parts of fore limb (shoulder, fore shank) & 58 & 13,6 \\
\cline { 2 - 4 } & Proximal parts of rear limb (butt, leg, hind shank) & 45 & 10,5 \\
\cline { 2 - 4 } & Total & 177 & 41,4 \\
\hline \multirow{3}{*}{$\begin{array}{l}\text { Not very valuable } \\
\text { parts of carcass }\end{array}$} & Head (brawn) & 195 & 45,6 \\
\cline { 2 - 4 } & Distal parts of fore limb (trotters/feet) & 22 & 5,1 \\
\cline { 2 - 4 } & Distal parts of rear limb (trotters/feet) & 34 & 7,9 \\
\cline { 2 - 4 } & Total & 251 & 58,6 \\
\hline Total & 428 & 100 \\
\hline
\end{tabular}


Table 12. Niedźwiedź, site 1. Measurements $(\mathrm{mm})$ of cattle horncores. Measurements: 1 - horncore basal circumference, 2 - greatest diameter of the horncore base, 3 - least diameter of the horncore base, 4 - length of the outer curvature of the horncore, 5 - index, 6 - sex (fe. - female person, m. - male person, o. - ox), 7 - points

\begin{tabular}{|c|c|c|c|c|c|c|c|c|c|c|}
\hline $\begin{array}{c}\text { Measure- } \\
\text { ments }\end{array}$ & \multicolumn{10}{|c|}{ Results } \\
\hline 1 & 138,5 & 144,0 & 144,5 & 149,0 & $(150,0)$ & 154,0 & 154,0 & 159,0 & 161,0 & 165,0 \\
\hline 2 & 48,5 & 50,0 & 53,0 & 53,0 & 53,0 & 52,5 & 56,0 & 56,0 & 54,0 & 56,6 \\
\hline 3 & 39,5 & 41,0 & 38,5 & 40,0 & $(40,4)$ & 44,0 & 40,5 & 42,5 & 44,5 & 45,0 \\
\hline 4 & $(168,0)$ & 235,0 & - & 200,0 & $(220,0)$ & - & 246,0 & - & - & - \\
\hline 5 & 81,4 & 82,0 & 70,0 & 75,5 & 76,4 & 83,8 & 72,0 & 75,9 & 82,4 & 79,6 \\
\hline 6 & fe. & fe. & fe. & fe. & fe. & fe. & fe. & fe. & fe. & m. \\
\hline 7 & 24 & 27 & 28 & 31 & 31 & 34 & 34 & 37 & 38 & 41 \\
\hline
\end{tabular}

\begin{tabular}{|c|c|c|c|c|c|c|c|c|c|c|}
\hline $\begin{array}{c}\text { Measure- } \\
\text { ments }\end{array}$ & \multicolumn{10}{|c|}{ Results } \\
\hline 1 & 169,0 & 170,0 & 173,0 & 184,0 & 195,5 & 201,5 & 223,0 & 230,0 & 232,0 & $(241,0)$ \\
\hline 2 & 60,5 & 61,0 & 61,0 & 65,0 & 70,5 & 75,5 & 77,0 & 80,0 & 81,0 & 82,0 \\
\hline 3 & 44,0 & 45,5 & 48,0 & 51,0 & 52,5 & 52 & 60,0 & 62,0 & 62,0 & 65,0 \\
\hline 4 & - & - & - & - & 300 & - & - & 292,0 & - & - \\
\hline 5 & 72,7 & 74,6 & 78,7 & 78,4 & 74,5 & 68,9 & 77,9 & 77,5 & 76,5 & 79,3 \\
\hline 6 & fe. & fe. & fe. & fe. & fe. & fe. & o. & m. & \multicolumn{2}{|c|}{ o. } \\
\hline 7 & 43 & 44 & 46 & 52 & 60 & 63 & 77 & 81 & 82 & 88 \\
\hline
\end{tabular}

\begin{tabular}{|c|c|c|c|}
\hline Measure- & \multicolumn{3}{|c|}{ Results } \\
\hline 1 & 249,0 & 249,0 & 254,0 \\
\hline 2 & 83,0 & 84,0 & 90,0 \\
\hline 3 & 66,5 & 65,5 & 72,0 \\
\hline 4 & - & - & - \\
\hline 5 & 80,1 & 78,0 & 80,0 \\
\hline 6 & \multicolumn{2}{|c|}{ o. } & o. \\
\hline 7 & 93 & 93 & 96 \\
\hline
\end{tabular}


Table 13. Niedźwiedź, site 1. Measurements $(\mathrm{mm})$ of cattle scapulae. Measurements: 1 - smallest length of the Collum scapulae, 2 - points

\begin{tabular}{|c|c|c|c|c|c|c|c|c|c|}
\hline $\begin{array}{c}\text { Measure- } \\
\text { ments }\end{array}$ & \multicolumn{10}{|c|}{ Results } \\
\hline 1 & 43,5 & 48,0 & 50,0 & 52,5 & 53,0 & 58,0 & 62,0 & 65,0 & 67,5 \\
\hline 2 & 44 & 52 & 60 & 66 & 67 & 80 & 90 & 97 & 104 \\
\hline
\end{tabular}

Table 14. Niedźwiedź, site 1. Measurements $(\mathrm{mm})$ of cattle humeri. Measurements: 1 - greatest breadth of the distal end, 2 - points

\begin{tabular}{|c|c|c|c|c|c|c|c|c|c|c|}
\hline $\begin{array}{c}\text { Measure- } \\
\text { ments }\end{array}$ & \multicolumn{10}{|c|}{ Results } \\
\hline 1 & 75,0 & 78,5 & 79,0 & $84,0 \times 2$ & 85,0 & 87,0 & 88,0 & 90,5 & 93,0 & 94,0 \\
\hline 2 & 50 & 57 & 58 & $68 \times 2$ & 70 & 74 & 76 & 81 & 86 & 88 \\
\hline
\end{tabular}

\begin{tabular}{|c|c|c|}
\hline $\begin{array}{c}\text { Measure- } \\
\text { ments }\end{array}$ & \multicolumn{2}{|c|}{ Results } \\
\hline 1 & 95,0 & 97,5 \\
\hline 2 & 90 & 95 \\
\hline
\end{tabular}

Table 15. Niedźwiedź, site 1. Measurements $(\mathrm{mm})$ of cattle radii. Measurements: 1 - greatest breadth of the proximal end, 2 - greatest breadth of the distal end, 3 - points

\begin{tabular}{|c|c|c|c|c|c|c|c|c|}
\hline $\begin{array}{c}\text { Measure- } \\
\text { ments }\end{array}$ & \multicolumn{9}{|c|}{ Results } \\
\hline 1 & 88,5 & 96,5 & 101,5 & - & - & - & - & - \\
\hline 2 & - & - & - & 71,0 & 72,5 & 79,0 & 79,5 & 89,5 \\
\hline 3 & 46 & 66 & 79 & 77 & 81 & 97 & 99 & 124 \\
\hline
\end{tabular}


Table 16. Niedźwiedź, site 1. Measurements $(\mathrm{mm})$ of cattle metacarpi. Measurements: 1 - greatest length, 2 - greatest breadth of the proximal end, 3 - smallest breadth of the diaphysis, 4 - greatest breadth of the distal end, 5 - diaphysis breadth index, 6- sex (fe. - female person, m. - male person), 7- withers height ( $\mathrm{cm}$ ), 8 - points

\begin{tabular}{|c|c|c|c|c|c|c|c|c|c|c|}
\hline $\begin{array}{c}\text { Measure- } \\
\text { ments }\end{array}$ & \multicolumn{10}{|c|}{ Results } \\
\hline 1 & 203,5 & 215,0 & - & - & - & - & - & - & - & - \\
\hline 2 & 62,5 & 72,0 & $52,5 \times 2$ & 55,0 & 55,5 & 58,0 & 59,0 & 71,0 & - & - \\
\hline 3 & 34,5 & 41,0 & - & - & - & - & - & - & - & - \\
\hline 4 & 62,0 & 71,0 & - & - & - & - & - & - & $57 \times 3$ & 59,5 \\
\hline 5 & 16,9 & 19,1 & - & - & - & - & - & - & - & - \\
\hline 6 & fe. & $\mathrm{m}$. & - & - & - & - & - & - & - & - \\
\hline 7 & 122,7 & 136,1 & - & - & - & - & - & - & - & - \\
\hline 8 & $\begin{array}{c}67,61,62, \\
50,54\end{array}$ & $\begin{array}{c}81,85,95, \\
72,77\end{array}$ & $36 \times 2$ & 42 & 44 & 50 & 52 & 82 & $37 \times 3$ & 44 \\
\hline
\end{tabular}

\begin{tabular}{|c|c|c|c|}
\hline $\begin{array}{c}\text { Measure- } \\
\text { ments }\end{array}$ & \multicolumn{3}{|c|}{ Results } \\
\hline 1 & - & - & - \\
\hline 2 & - & - & - \\
\hline 3 & - & - & - \\
\hline 4 & 60,5 & 69,0 & $71 \times 2$ \\
\hline 5 & - & - & - \\
\hline 6 & - & - & - \\
\hline 7 & - & - & - \\
\hline 8 & 46 & 67 & $72 \times 2$ \\
\hline
\end{tabular}

Table 17. Niedźwiedź, site 1. Measurements $(\mathrm{mm})$ of cattle femurs. Measurements: 1 - greatest breadth of the distal end, 2 - points

\begin{tabular}{|c|c|c|c|}
\hline Measurements & \multicolumn{3}{|c|}{ Results } \\
\hline 1 & 82,5 & 90,0 & 98,0 \\
\hline 2 & 21 & 40 & 60 \\
\hline
\end{tabular}

Table 18. Niedźwiedź, site 1. Measurements $(\mathrm{mm})$ of cattle tibiae. Measurements: 1 - greatest breadth of the distal end, 2 - points

\begin{tabular}{|c|c|c|c|c|c|c|c|c|c|c|c|}
\hline $\begin{array}{c}\text { Measure- } \\
\text { ments }\end{array}$ & \multicolumn{10}{|c|}{ Results } \\
\hline 1 & 59,0 & 59,5 & 60,0 & $61,0 \times 2$ & 63,5 & 64,5 & 65,0 & 68,0 & 69,5 & 72,0 & 72,5 \\
\hline 2 & 38 & 39 & 40 & $42 \times 2$ & 47 & 49 & 50 & 56 & 59 & 64 & 65 \\
\hline
\end{tabular}


Table 19. Niedźwiedź, site 1. Measurements $(\mathrm{mm})$ of cattle tali. Measurements: 1 - greatest length, 2 - points

\begin{tabular}{|c|c|c|c|c|c|c|c|c|c|c|c|}
\hline $\begin{array}{c}\text { Measure- } \\
\text { ments }\end{array}$ & \multicolumn{10}{|c|}{ Results } \\
\hline 1 & 57,0 & 63,0 & 63,5 & 64,0 & 66,0 & 66,5 & 67,0 & $68,0 \times 2$ & 68,5 & 69,0 & $70,0 \times 2$ \\
\hline 2 & 27 & 42 & 44 & 45 & 50 & 51 & 52 & $55 \times 2$ & 56 & 57 & $60 \times 2$ \\
\hline
\end{tabular}

Table 20. Niedźwiedź, site 1. Measurements $(\mathrm{mm})$ of cattle calcanei. Measurements: 1 - greatest length, 2 - points

\begin{tabular}{|c|c|c|c|c|c|c|}
\hline $\begin{array}{c}\text { Measure- } \\
\text { ments }\end{array}$ & \multicolumn{7}{|c|}{ Results } \\
\hline 1 & 125,0 & 128,0 & 131,0 & 132,5 & 134,0 & 147,5 \\
\hline 2 & 62 & 70 & 77 & 81 & 85 & 119 \\
\hline
\end{tabular}

Table 21. Niedźwiedź, site 1. Measurements $(\mathrm{mm})$ of cattle metatarsi. Measurements: 1 - greatest breadth of the proximal end, 2 - points

\begin{tabular}{|c|c|c|c|c|c|c|c|}
\hline $\begin{array}{c}\text { Measure- } \\
\text { ments }\end{array}$ & \multicolumn{7}{|c|}{ Results } \\
\hline 1 & 45,5 & 47,0 & 48,0 & 49,5 & 50,0 & $51,0 \times 2$ & 51,5 \\
\hline 2 & 52 & 57 & 60 & 65 & 67 & $70 \times 2$ & 72 \\
\hline
\end{tabular}

Table 22. Niedźwiedź, site 1. Measurements $(\mathrm{mm})$ of cattle phalanges I. Measurements: 1 - greatest length of the peripheral half, 2 - points

\begin{tabular}{|c|c|c|c|c|c|c|c|c|c|c|}
\hline $\begin{array}{c}\text { Measure- } \\
\text { ments }\end{array}$ & \multicolumn{10}{|c|}{ Results } \\
\hline 1 & $55,0 \times 3$ & $56,0 \times 2$ & $57,0 \times 2$ & 58,5 & 59,0 & $59,5 \times 3$ & $60,0 \times 2$ & 60,5 & $61,0 \times 2$ & 61,5 \\
\hline 2 & $37 \times 3$ & $40 \times 2$ & $42 \times 2$ & 46 & 47 & $49 \times 3$ & $50 \times 2$ & 51 & $52 \times 2$ & 54 \\
\hline
\end{tabular}

\begin{tabular}{|c|c|c|c|c|c|c|c|c|c|c|c|}
\hline $\begin{array}{c}\text { Measure- } \\
\text { ments }\end{array}$ & \multicolumn{10}{|c|}{ Results } \\
\hline 1 & $62,0 \times 2$ & 63,0 & 63,5 & 64,0 & 64,5 & 65,0 & 65,5 & 66,0 & $67,0 \times 2$ & 68,5 & 69,5 \\
\hline 2 & $55 \times 2$ & 57 & 59 & 60 & 61 & 62 & 64 & 65 & $67 \times 2$ & 71 & 74 \\
\hline
\end{tabular}


Table 23. Niedźwiedź, site 1. Measurements $(\mathrm{mm})$ of goats/sheep horncores. Measurements: 1 - horncore basal circumference, 2 - greatest diameter of the horncore base, 3 - least diameter of the horncore base, 4 - length of the outer curvature of the horncore, 5 - species, 6 - sex (fe. - female person, m. - male person, o. - ox)

\begin{tabular}{|c|c|c|c|c|c|c|}
\hline Measurements & \multicolumn{7}{|c|}{ Results } \\
\hline 1 & 98,0 & 122,0 & 89,0 & 104,0 & 119,0 & 137,0 \\
\hline 2 & 37,0 & 46,0 & 34,5 & 38,0 & 46,0 & 53,5 \\
\hline 3 & 25,5 & 31,5 & 18,5 & 25,0 & 26,5 & 32,5 \\
\hline 4 & 175,0 & 219,0 & 92,0 & 114,5 & 142,5 & - \\
\hline 5 & Capra $h$. & Capra $h$. & Ovis $a$. & Ovis $a$. & Ovis $a$. & Ovis $a$. \\
\hline 6 & fe. & $\mathrm{m}$. & fe. & fe. & fe. & o. \\
\hline
\end{tabular}

Table 24. Niedźwiedź, site 1. Measurements $(\mathrm{mm})$ of sheep metacarpi. Measurements: 1 - greatest length, 2 - greatest breadth of the proximal end, 3 - smallest breadth of the diaphysis, 4 - greatest breadth of the distal end, 5 - withers height $(\mathrm{cm})$

\begin{tabular}{|c|c|c|}
\hline Measurements & \multicolumn{2}{|c|}{ Results } \\
\hline 1 & 127,0 & 127,5 \\
\hline 2 & 21,5 & 23,0 \\
\hline 3 & 13,5 & 15,5 \\
\hline 4 & 26,5 & 25,5 \\
\hline 5 & 62,1 & 62,3 \\
\hline
\end{tabular}

Table 25. Niedźwiedź, site 1. Measurements $(\mathrm{mm})$ of sheep metatarsus. Measurements: 1 - greatest length, 2 - greatest breadth of the proximal end, 3 - smallest breadth of the diaphysis, 4 - greatest breadth of the distal end, 5 - withers height $(\mathrm{cm})$

\begin{tabular}{|c|c|}
\hline Measurements & Results \\
\hline 1 & 130,0 \\
\hline 2 & 20,0 \\
\hline 3 & 11,5 \\
\hline 4 & 24,0 \\
\hline 5 & 59,0 \\
\hline
\end{tabular}


Table 26. Niedźwiedź, site 1. Measurements $(\mathrm{mm})$ of pig mandibles. Measurements: 1 - greatest diameter of the canine alveolus, 10 - sex (fe. - female person, m. - male person)

\begin{tabular}{|c|c|c|c|c|}
\hline Measurements & \multicolumn{4}{|c|}{ Results } \\
\hline 1 & 12,0 & 19,5 & 20,0 & $23,0 \times 2$ \\
\hline 2 & $\mathrm{fe}$. & $\mathrm{m}$. & $\mathrm{m}$. & $\mathrm{m}$. \\
\hline
\end{tabular}

Table 27. Niedźwiedź, site 1. Measurements $(\mathrm{mm})$ of pig scapulae. Measurements: 1 - smallest length of the Collum scapulae, 2 - points

\begin{tabular}{|c|c|c|c|c|c|c|}
\hline Measurements & \multicolumn{7}{|c|}{ Results } \\
\hline 1 & 21,5 & 22,5 & 23,5 & 25,0 & $26,0 \times 2$ & 27,0 \\
\hline 2 & 54 & 62 & 71 & 83 & $92 \times 2$ & 100 \\
\hline
\end{tabular}

Table 28. Niedźwiedź, site 1. Measurements $(\mathrm{mm})$ of pig humeri. Measurements: 1 - greatest breadth of the distal end, 2 - points

\begin{tabular}{|c|c|c|c|c|c|c|c|}
\hline Measurements & \multicolumn{7}{|c|}{ Results } \\
\hline 1 & 39,0 & 40,0 & 40,5 & 41,0 & 41,5 & 43,0 & 44,5 \\
\hline 2 & 69 & 75 & 78 & 81 & 84 & 94 & 103 \\
\hline
\end{tabular}

Table 29. Niedźwiedź, site 1. Measurements $(\mathrm{mm})$ of pig metacarpi. Measurements: 1 - greatest length, 2 - number of bone, 3 - withers height $(\mathrm{cm}), 4$ - points

\begin{tabular}{|c|c|c|}
\hline Measurements & \multicolumn{2}{|c|}{ Results } \\
\hline 1 & 73,0 & 74,5 \\
\hline 2 & III & IV \\
\hline 3 & 78,3 & 78,4 \\
\hline 4 & 87 & 88 \\
\hline
\end{tabular}

Table 30. Niedźwiedź, site 1. Measurements $(\mathrm{mm})$ of pig tibiae. Measurements: 1 - greatest breadth of the distal end, 2 - points

\begin{tabular}{|c|c|c|c|c|c|c|}
\hline Measurements & \multicolumn{6}{|c|}{ Results } \\
\hline 1 & $30,0 \times 2$ & $31,0 \times 2$ & 31,5 & 32,0 & 32,5 & $33,0 \times 3$ \\
\hline 2 & $67 \times 2$ & $78 \times 2$ & 83 & 89 & 94 & $100 \times 3$ \\
\hline
\end{tabular}


Table 31. Niedźwiedź, site 1. Measurements $(\mathrm{mm})$ of pig tali. Measurements: 1 - greatest length, 2 - withers height $(\mathrm{cm}), 3$ - points

\begin{tabular}{|c|c|c|c|c|c|}
\hline Measurements & \multicolumn{5}{|c|}{ Results } \\
\hline 1 & 41,0 & $44,0 \times 2$ & 44,5 & 45,5 & 46,5 \\
\hline 2 & 73,4 & $78,8 \times 2$ & 79,6 & 81,4 & 83,2 \\
\hline 3 & 77,68 & $100 \times 2,89 \times 2$ & 104,93 & 111,100 & 119,107 \\
\hline
\end{tabular}

Table 32. Niedźwiedź, site 1. Measurements $(\mathrm{mm})$ of pig calcaneus. Measurements: 1 - greatest length, 2 - withers height $(\mathrm{cm}), 3$ - points

\begin{tabular}{|c|c|}
\hline Measurements & Results \\
\hline 1 & 80 \\
\hline 2 & 74,7 \\
\hline 3 & 68,73 \\
\hline
\end{tabular}

Table 33. Niedźwiedź, site 1. Measurements $(\mathrm{mm})$ of pig metatarsus. Measurements: 1 - greatest length, 2 - number of bone, 3 - withers height $(\mathrm{cm}), 4$ - points

\begin{tabular}{|c|c|}
\hline Measurements & Results \\
\hline 1 & 92,5 \\
\hline 2 & IV \\
\hline 3 & 81,8 \\
\hline 4 & 101 \\
\hline
\end{tabular}

Table 34. Niedźwiedź, site 1. Measurements $(\mathrm{mm})$ of dog tibia. Measurements: 1 - greatest length, 2 - greatest breadth of the proximal end, 3 - smallest breadth of the diaphysis, 4 - greatest breadth of the distal end, 5 - withers height $(\mathrm{cm})$

\begin{tabular}{|c|c|}
\hline Measurements & Results \\
\hline 1 & 135,5 \\
\hline 2 & 27,0 \\
\hline 3 & 9,0 \\
\hline 4 & 17,5 \\
\hline 5 & 40,5 \\
\hline
\end{tabular}




\section{References}

Bökönyi S. 1970. A new method for determination of the number of individuals in animal bone material. American Journal of Archaeology 74, 291-292.

Bökönyi S. 1984. Animal husbandry and hunting in Tác-Gorsium. The vertebrate fauna of a Roman town in Pannonia. Budapest: Publishing House of the Hungarian Academy of Sciences.

Chaplin R.E. 1971. The Study of Animal Bones from Archaeological Sites. London-New York: Seminar Press.

Driesch A. 1976. A guide to the measurement of animal bones from archaeological sites. Peabody Museum Bulletins 1, I-IX + 1-137.

Głowacka I. 1964. Atlas rozbioru na części tusz zwierząt rzeźnych oraz obróbki wstępnej dziczyzny, drobiu i ryb. Warszawa: Wydawnictwo Przemysłu Lekkiego i Spożywczego.

Harcourt R. A. 1974. The Dog in Prehistoric and Early Historic Britain. Journal of Archaeological Science 1, 151-175.

Kruk J. 1980. Gospodarka $w$ Polsce południowo-wschodniej $w$ V-III tysiacleciu p.n.e. Wrocław: Ossolineum.

Krysiak K. 1950. Szczątki zwierzęce z osady neolitycznej w Ćmielowie. Wiadomości Archeologiczne $17,165-228$.

Krysiak K. 1952. Szczątki zwierzęce z osady neolitycznej w Ćmielowie, 2. Wiadomości Archeologiczne 18(3-4), 251-290.

Krysiak K. 1956. Materiał zwierzęcy z osady neolitycznej w Gródku Nadbużnym, pow. Hrubieszów. Wiadomości Archeologiczne 23(1), 49-58.

Krysiak K.1966. Szczątki zwierzęce z osady neolitycznej w Zawichoście-Podgórzu, pow. Sandomierz. Wiadomości Archeologiczne 32, 376-384.

Krysiak K. and Lasota A. 1971. Zwierzęce materiały kostne z osady Kamień Łukawski, pow. Sandomierz. Wiadomości Archeologiczne 36(2), 187-200.

Lasota-Moskalewska A. 2005. Zwierzęta udomowione w dziejach ludzkości. Warszawa: Wydawnictwa Uniwersytetu Warszawskiego.

Lasota-Moskalewska A. 2008. Archeozoologia. Ssaki. Warszawa: Wydawnictwa Uniwersytetu Warszawskiego.

Lasota-Moskalewska A., Kobryń H. and Świeżyński K. 1998. The size of domestic sheep (Ovis aries L.) in Europe and Asia from the Neolithic to the Middle Ages. Światowit 41(B), 323-348.

Makowicz-Poliszot D. 1983. Hodowla zwierząt u społeczności ludzkich dorzecza górnej Wisły w eneolicie i we wczesnej epoce brązu (Uwagi o programie badań). Sprawozdania Archeologiczne 35, 263-274.

Makowicz-Poliszot D. 2002. Zwierzęce szczątki kostne ze stanowiska kultury pucharów lejkowatych w Zawarży. In A. Kulczycka-Leciejewiczowa, Zawarża. Osiedle neolityczne w poludniowopolskiej strefie lessowej. Wrocław: Instytut Archeologii i Etnologii PAN O/Wrocław, 135-160.

Makowicz-Poliszot D. 2007. Fauna of the upper Vistula River basin - an analysis based on bone material from selected sites of the Funnel Beakers Culture. Sprawozdania Archeologiczne 59, 143-180. 
Matolcsi J. 1970. Historische Erforschung der Kőrpergrősse des Rindes auf Grund von ungarischen Knochenmaterial. Zeitschrift für Tierzüchtung und Züchtungsbiologie 87/2, 89-137.

Milisauskas S., Kruk J., Pipes M.-L. and Makowicz-Poliszot D. 2012. Butchering and Meat Consumption in the Neolithic. The Exploitation of Animals at Bronocice. Ubój i mięso. Aspekty neolitycznej gospodarki zwierzęcej. Bronocice - studium przypadku. Kraków: Instytut Archeologii i Etnologii PAN.

Teichert M. 1969. Osteometrische Untersuchungen zur Berechnung der Widerristhöhe bei vor- und frühgeschichtlichen Schweinen. Küh Archiv 83/3, 237-292.

Teichert M. 1975. Osteometrische Untersuchungen zur Berechnung der Widerristhöhe bei Schafen. In A. T. Clason (ed.), Archeozoological studies. Amsterdam, Oxford, New York: North-Holland Publishing Company, American Elsevier Publishing Company, 51-69.

Uerpmann H. P. 1972. Tierknochenfunde und Wirtschaftsarchäologie. Eine kritische Studie der Methoden der Osteo-Archäologie, Abhandlungen und Berichte. Archäologische Informationen 1, 9-27.

Wyrost P. 1963. Badania nad typami psów wczesnośredniowiecznego Opola i Wrocławia. Silesia Antiqua 5, 198-233. 
